The Plural Temporalities of Hegemony

Peter D. Thomas

Institutional affiliation:

Department of Politics, History and the Brunel Law School, Brunel University

London, UK

Postal Address:

Politics and History

Brunel University

Kingston Lane

Uxbridge

UB8 3PH

UK

Email address:

PeterD.Thomas@Brunel.ac.uk

Biographical note:

Peter D. Thomas teaches political philosophy and the history of political thought at

Brunel University London. He is the author of The Gramscian Moment: Philosophy,

Hegemony and Marxism (Brill, 2009) and co-editor of Encountering Althusser:

Politics and Materialism in Contemporary Radical Thought (Bloomsbury, 2012). 


\title{
The Plural Temporalities of Hegemony
}

\author{
Abstract
}

Louis Althusser’s critique of Gramsci’s ‘absolute historicism’ was the occasion for the elaboration of a distinctive notion of plural historical temporalities or times. In this article, I argue, first, that Althusser's theory of plural historical temporalities should be understood as integrally linked to his critique both of structuralism and of theories of the subject. Second, I argue that, Althusser's early criticisms notwithstanding, Gramsci can be understood to have elaborated a consistently nonformalist notion of constitutive temporal plurality, particularly with his notion of 'prevision' as a method of political work. Rather than culminating in a figure of temporal synchronisation, hegemonic politics should instead be thought as a mode of intervention that valorises, rather than negates, the 'non-presence of the present', or constitutive non-contemporaneity, as the fundamental condition of revolutionary politics.

Keywords: Louis Althusser; Antonio Gramsci; historical time; plural temporalities; hegemony 


\section{The Plural Temporalities of Hegemony}

But in every age, there has been a past and a contemporaneity, and calling oneself a “contemporary” cannot be anything but a joke. (The story is told of a little French bourgeois who put "Contemporary" on his calling card; he had discovered that he was a "contemporary" and bragged about it) (Q 8, §232, 1087). ${ }^{1}$

Notions of a plurality of historical times or temporalities have accompanied the materialist conception of history since Marx. ${ }^{2}$ Often obscured by orthodox defenders of Marxism and their critics alike, contemporary debates both within and outside the Marxist traditions have offered possibilities to recover notions of historical time richer than the teleological vision of the growth of productive forces with which Marxism has often been associated. The young Marx’s inheritance, mediated by Heine, of German idealism’s foundational and abiding reflections on Germany's miserable non-contemporaneity, both with Europe and with itself, is only the first in a long line of Marxist reflections on the political significance of the temporal disjointedness of modern historical experience (Kouvelakis 2003, 44-120). Marx’s mature critique of political economy emphasises the centrality of differential temporal determinations in the process of capital accumulation (Tombazos, 1995). Temporal unevenness is central to the terms in which Trotsky theorises both the reality of combined and uneven capitalist development and the possibility of permanent revolution, insights developed in related though distinct terms by the political conclusions that Lenin draws from his theory of imperialism (Bensaïd, 2002). Lukács’s historicism and Benjamin’s anti-historicism, albeit in radically 
different ways, reformulated themes of temporal breaks in messianic conceptions of time, while Bloch provided one of the earliest formulations of the notion of a contemporaneity of the non-contemporaneous (Tomba, 2011; Harootunian, 2015).

Arguably, however, it was Althusser's contribution to Reading Capital in the early 1960s that has most influentially registered the theme of plural historical times for contemporary Marxism (Osborne 1995; Morfino, 2009 and 2014). Tentatively announced in the chapter of Reading Capital entitled 'The Errors of Classical Economics: An Outline for a Concept of Historical Time’, the subsequent chapter, 'Marxism is not an Historicism', attempted to develop an alternative to the ‘ideological conception of historical time’ (Althusser and Balibar 1970, 96) that Althusser held to characterise a wide range of modern theories of history, beginning with Hegel's absolute idealism and culminating in the 'absolute historicism' that he associated with one of his most enduring interlocutors, Antonio Gramsci. According to Althusser, both Hegel and, following him, Gramsci, had privileged notions of presence, such that temporal difference was ultimately comprehended in terms of the unity of a synchronising

‘essential section' (coupe d'essence), an intellectual operation in which a vertical break is made at any moment in historical time, a break in the present such that all the elements of the whole revealed by this section are in an immediate relationship with one another, a relationship that immediately expresses their internal essence (Althusser and Balibar 1970, 94).

Althusser's notion of plural historical temporalities instead aimed to theorise the 
elements of relationality and above all dislocation [décalage] that constitutively prevent the identity of the present with itself, revealing its presumed unity to be a real plurality. This was not a phenomenological emphasis upon a diversity of subjective temporal experiences; Althusser’s strident theoretical anti-humanism expressly precluded recourse to such a conception. Nor was it an attempt to analyse the present as an 'uneven section', in which different times coexisted within a primary single and homogenous time, or were measured by the 'line of a single continuous reference time'; this was precisely the view that Althusser ascribed to the Annales school, and from which he was at pains to take his distance (Althusser and Balibar 1970, 105; see Schöttler 1993). Rather, Althusser aimed to theorize the disjointed nature of historical time itself. He argued that

It is not enough, therefore, to say ... that each time has its own rhythms, some short, some long; we must also think these differences in rhythm and punctuation in their foundation, in the type of articulation, displacement and torsion which harmonises these different times with on another (Althusser and Balibar 1970, 100). ${ }^{3}$

Far from expressive of a 'primordial' essence, the present for Althusser thus needed to be thought as an articulation of plural temporalities without common measure. In this sense, Reading Capital's 'outline’ for a concept of historical time could only with difficulty be regarded as 'structuralist', because it seems to deny in principle the synchronic unification that structuralism, at least in its 'classical' formulations, presupposes.

However, whether or not such a conception of 'originary' temporal plurality 
was sufficient, on its own, to resist the synchronising force of what Reading Capital had called the 'single ideological base time’ $(1970,105)$ of the established political order remained an open question in the Althusserian project in the early 1960s. On the one hand, Althusser's notions of a 'decentred structure' and above all of 'conjuncture' aimed to analyse the co-existence of plural times in the 'real historical present' in terms that did not reduce them to a common measure, but instead emphasized the dynamic of their relation. ${ }^{4}$ On the other hand, some elements of this early work, particularly the seemingly more 'structuralist' vocabulary used in treating questions of periodization and transition, might be argued to presuppose a a certain type of synchronisation. While the resultant unity (of, for instance, the mode of production) is depicted as a contingent or provisional result rather than as 'essential' origin, insofar as the articulated elements were posited as composing a structured present (albeit decentred), this re-opened the way to thinking those plural times according to the common measure of the structure, rather than in terms of their singular relations. ${ }^{5}$

Althusser's turn to a theory of the interpellated subject - or more precisely, of a 'subject effect' - from the mid-1960s onwards might be regarded as, in part, an attempt to address the recurrent threat of (re-) synchronisation, though it was never explicitly thematised in this direction by Althusser himself. The 'bad subjects' (Althusser 1971, 181) who refuse interpellation by the existing order could in this sense be understood as Träger of temporal diversity, resisting the lures of synchronisation and maintaining a plurality of times distinct from the 'single ideological base time'. In this case, however, it is not clear if Althusser has thereby avoided falling into precisely the 'formalism' he had consistently denounced from his earliest works. ${ }^{6}$ For insofar as this 'subjected subject' would seem to be conceived in 
terms of what Jacques-Alain Miller influentially theorised as an 'action of the structure' (Miller 2012), it seems to presume a synchronic structure as its condition of possibility, even while it exceeds it.

In this article, I argue, first, that Althusser's theory of plural historical temporalities should be understood as integrally linked to his critique of the 'formalism' both of structuralism and of theories of the subject. Against the return to an (albeit radically renovated) notion of the subject in Althusser's later work (and in much post-Althusserianism), I argue that the interventions of For Marx and Reading Capital can be read as proposing a more radical rejection of the category of the subject as such, particularly when considered in terms of its temporal implications. Second, I argue that, Althusser's early criticisms notwithstanding, Gramsci can be understood to have elaborated a consistently non-formalist notion of constitutive temporal plurality. In particular, his concept of ‘prevision' [previsione] as a method of political work provides the outlines of an expansive historical process not of temporal synthesis but of differentiation. Rather than culminating in a figure of temporal synchronisation (a 'political subject'), hegemonic politics should thus be thought as a mode of intervention that valorises, rather than negates, the 'nonpresence of the present', or constitutive non-contemporaneity, as the fundamental condition of revolutionary politics.

\section{The impossibility of a Hegelian politics}

Althusser's emphasis upon temporal plurality played an important role in debates in the 1960s and 1970s. ${ }^{7}$ The opprobrium into which his name fell for a long period, however, tended to work against a continuation of the discussion of the 
conceptual coherence and political consequences of his notion of historical time. Other thinkers of temporal diversity, such as Bloch and, more recently, Koselleck, have become more influential in general discussions of these themes. ${ }^{8}$ While the revival of interest in Althusser's work over the last 15 years initially focused on his newly published later writings, the subsequent turn to a re-reading of his early work in terms that stress the distance from the 'structuralism' to which the early Althusserian project was often reduced (Goshgarian 2012; Montag 2013) has also led to a reassessment of his theory of historical time and plural temporalities (Hindess 2007; Morfino 2009 and 2014; Chambers 2011). Rather than structuralism’s most notorious theorist, we are now beginning to see that Althusser might instead be regarded as one of its earliest and most radical critics. ${ }^{9}$

Indeed, Althusser consistently argued that an idealist conception of structure presupposes a unitary conception of temporal presence, as the expressivist form of an essence; in its turn, this leads to an essentially aestheticised concept of history, as a succession of 'essential sections' of contemporaneity, which are always formally identical with each other insofar as manifestations of an always self-same essence. History, in the sense of causally related events, or a process of development that can be rationally explained, becomes unthinkable. Instead, each historical period is represented effectively as merely a 'mobile image of eternity', in the sense ascribed to time itself in the Timaeus (37d), or, in Hegel's terms, a finite form of the infinity of the self-alienating concept. In such an Hegelian perspective, time is a means for the concept's re-presentation, while remaining within its own self-identical essence; as a circular process of the appearance of an essence that always returns to itself throughout the unfolding of its self-alienation, time is represented as merely accumulation within the concept, its mode of self-same expansion or intensification. 
The present would be fully identical with itself, in the sense that it would include nothing that could escape the determinations of its essence. On the basis of such an essentialization and thus eternalization of the present, there is no possibility of thinking change, other than in the form of the miraculous event that arrives, unexpectedly and above all inexplicably, from some 'beyond'. As Reading Capital declared, 'the ontological category of the present prevents any anticipation of historical time, any conscious anticipation of the future development of the concept, any knowledge of the future ... The fact that there is no knowing the future prevents there being any science of politics, any knowing that deals with the future effects of present phenomena’ (Althusser and Balibar 1970, 95).

Furthermore, if the notion of history as development premised upon the real difference of complexity is replaced by the indifference of 'differences' equal to each other in a 'spiritual' whole, there is little possibility of thinking transformative political practices that would usher in genuinely new forms of socio-political organisation. As Althusser famously remarked in 'On the Materialist Dialectic', a text that develops a 'spatial' critique of a spiritualised conception of the social formation that corresponds to the 'temporal' focus pursued in Reading Capital, 'It is no accident that the Hegelian theory of the social totality has never provided the basis for a policy, that there is not and cannot be a Hegelian politics’ (Althusser 1969, 204; see also Althusser and Balibar 1970, 95). It would perhaps be more precise to argue that, while politics understood as a formalist repetition of existing governmental forms may indeed be possible on such a basis (as the historical record amply attests), a properly revolutionary or transformative politics is not, for such change necessarily posits the emergence of hitherto unknown dimensions of socio-political organisation.

For Althusser, essentialist theories of the social totality and their 
corresponding (ideological) concept of historical time, such as those found in Hegel and Gramsci, could give rise at the most only to a politics of management, or administrative rearrangement of the status quo ('reformism'); its goal would be knowledge of the apparently diverse but essentially identical component elements of an homogenous present, in order to master them. Such an 'contemplative' perspective, however, seems to presuppose that any given present of the social totality is represented as an 'object' [Objekt], in the specific sense that Marx ascribed to this term in the first of his Theses on Feuerbach: the formal concept of the object of a contemplating subject (as distinct from a conception of the object as constituted in and by its relations, expressed for Marx in the term Gegenstand). ${ }^{10}$ An essentialist theory of the social totality thus presupposes not only that the totality is an organization of 'objects' [Objekte], but also a theory of a contemplating subject as their regulative instance; it is in fact the implicit positing of a subject of this type that is the condition of possibility for the appearance of the world as an 'exposition' of objects in the first place.

If conceived in these terms, politics would quickly come to function as a type of knowledge 'produced' by a subject 'abstracting' from the real. Formulating Althusser's argument in Hegelian metaphors, we could say that politics would be represented as a 'self-consciousness' of the structure of the social totality (here functioning as the equivalent of 'consciousness'), the moment that provides the social totality with knowledge of itself as unified and self-identical. As such, politics would thus be regarded as the goal inscribed in the origin of the social totality, as its moment of completion or self-perfection, as fully contemporaneous with itself. The only meaningful form of political conflict would then consist in the contest between various claims to embody such a contemplative comprehension of the 'essential 
section' of the present. In other words, politics would become the clash of different 'subjects' claiming to have privileged knowledge of the 'object' of the present, which would be represented simultaneously as the Kampfplatz upon which they contend, and as the spoils of their eventual victory or defeat. Each subject would aim to assert its claims to be recognised as the 'authentic' self-consciousness of the present, because, qua self-consciousness, its knowledge would ultimately be knowledge of itself, reflecting upon itself. As Althusser's expansive definition of 'empiricism’ suggests, however, such knowledge could be gained only by means of supposing an 'abstraction from' or even 'extraction' of the 'essence of the object' on the part of the subject (Althusser and Balibar 1970, 35-6; 38). In turn, this would be possible because subject and object would be supposed to derive from 'an original unity undivided between subject and object' (Althusser and Balibar 1970, 63), now fallen away from themselves and awaiting their unification in a redeemed, 'synchronised' present. In the words of For Marx, at the origin of Althusser's theoretical antihumanist offensive, 'an empiricism of the subject always corresponds to an idealism of the essence' (Althusser 1969, 227).

\section{An alternative philosophical grammar}

The critique of the formalism of the modern philosophical theory of the subject constituted perhaps the most radical of Althusser's theoretical anti-humanist claims, with profound implications for thinking the problem of plural temporalities. This aspect tends to be obscured in readings of Althusser's outline of a concept of historical time that focus on Reading Capital's treatment of the problems of transition and periodization alone. ${ }^{11}$ Althusser’ own later Kehre towards an arguably formalist 
theory of the interpellated subject, and the various theories of subject construction and constitution that have strongly characterised the various post-Althusserianisms, have similarly made it more difficult to grasp the full dimensions of the early Althusser's critique of the subject. ${ }^{12}$ Yet Althusser's initial notion of theoretical anti-humanism was not simply a critique of the notion of the subject conceived in terms of selfconsciousness, interiority, or even as a merely formal bearer of subjectivity; it was not, that is, merely a 'destitution' of 'the subject as arche (cause, principle, origin)', or as 'constitutive', in order reconstruct it as 'effect', or as 'constituted subjectivity' (Balibar 2003, 10). More radically, at least some of the early Althusser's formulations point towards a critique of the entire philosophical grammar of subject-object thought that has dominated modern Western philosophy, a philosophical grammar inscribed in the very structures of what, to use the young Wittgenstein's terms, is 'sayable' and thus ‘thinkable' in modern Western European languages. ${ }^{13}$

Althusser's expansion of the notion of 'empiricism' attempted to highlight a secret alliance that had united supposedly opposed materialist and idealist epistemologies; both posited knowledge as a process of the 'discovery’ of an 'essence' of the object by a knowing subject, rather than as active relationality. ${ }^{14}$ In For Marx, Althusser claimed that Marx 'drove the philosophical categories of the subject, of empiricism, of the ideal essence, etc., from all the domains in which they had been supreme ... Marx's materialism excludes the empiricism of the subject (and its inverse: the transcendental subject)' (Althusser 1969, 228-9). In Reading Capital, he argued that 'the question of the appropriation of the real, specific object of knowledge has to be posed: (1) in terms which exclude any recourse to the ideological solution contained in the ideological characters Subject and Object, or to the mutual mirror-recognition structure, in the closed circle of which they move' (Althusser and 
Balibar 1970, 55). The seeming performative contradiction of this formulation was overcome with the decisive (though always unstable) transition to the concepts of articulation, torsion and relationality. Reading Capital's key notion of the 'object of knowledge' was thereby effectively 'demoted' to the status of a 'placeholder' indicating the relationality inscribed in knowledge itself, in what For Marx had characterised as a 'historico-dialectical materialism of praxis’ (Althusser 1969, 229).

The true 'subjects' (in the sense of constitutive subjects of the process) are therefore not these occupants or functionaries, are not, despite all appearances, the ‘obviousness’ of the 'given’ of naïve anthropology, 'concrete individuals', 'real men' - but the definition and distribution of these places and functions. The true 'subjects' are these definers and distributors: the relations of production (and political and ideological social relations). But since these are 'relations', they cannot be thought within the category subject (Althusser and Balibar 1970, 180).

Althusser instead proposed to explore the development of an alternative philosophical grammar, which would stress singularity over generic formalism, relational articulation over structure, displacement over localisation and dislocation [décalage] over fixity (see, e.g., Althusser and Balibar 1970, 100, 104, 108). He was aware of the immense difficulty and perhaps even impossibility of a consistent elaboration of this project: 'It is true that much theoretical work is needed to deal with all the forms of this empiricism sublimated in the "theory of knowledge" which dominates Western philosophy, to break with its problematic of subject (cogito) and object - and all their variations' (Althusser and Balibar 1970, 184; my italics). The stakes for his outline of 
a concept of historical time, however, were high: only on the basis of resisting any reconstitution of the concept of structure, the terrain upon which 'subjects' and 'objects' could emerge, would it be possible to maintain a theory of plural temporality as constitutive, rather than an aberration that political engagement, whether revolutionary or not, should seek to overcome. And only on this basis would it be possible to think the conditions for a genuinely 'post-Hegelian politics'.

\section{Non-contemporaneity of the present}

Althusser had formulated many of the arguments in Reading Capital's theory of historical time explicitly as a critique of Gramsci’s residual Hegelianism, 'absolute historicism’ and concomitant ‘absolute humanism’. Produced before Gerratana’s critical edition of the Prison Notebooks (1975), and in the peculiar institutional environment of French academic philosophy in the early 1960s, it is not surprising that subsequent scholarship has called into question many of Althusser's substantive claims regarding not only Gramsci but also his depiction of Hegel. ${ }^{15}$ The great merit of Althusser's reading nevertheless remains that of having directed our attention to the theme of contemporaneity in Gramsci's thought; indeed, it was perhaps only the polemical force of Althusser's intervention that finally made it possible to read features of Gramsci's thought that previously had seemed illegible, beneath the level of visibility that an established interpretative tradition (the more Crocean than Gramscian historicism of the PCI) had allowed.

What emerges from this new scholarship is a vision of Gramsci as a preeminent theorist of the non-contemporaneity of the present. Nothing could be further from the orienting perspectives of Gramsci's thought than the notions of an 'essential 
section', of an expressivist totality, or of a homogenous 'present' that could be contemporaneous with itself. The Prison Notebooks can instead be regarded as an immense encyclopaedia of the numerous temporal 'dislocations' that characterise the distinctive nature of modern historical experience. One of the most striking examples of this 'non-presence of the present' in the Prison Notebooks can be found in Gramsci's reflections on the person [la persona] as 'bizarrely' composed of different layers of historical experience, from 'stone age elements' to 'principles of a more advanced science', in terms remarkably similar to those employed by Freud's famous analogy of Rome and the Unconscious (Q11, §12, 1376; cf. Urbinati 1998, 379). The person is thus conceived as an unstable organisation of conflicting 'molecular' tendencies, times, intensities and durations, provisionally and precariously united in the contemporaneity of a consistent or 'coherent' personhood usually only by the dominance of the temporal order of the state and its regulatory rhythms in the labour process and daily life. ${ }^{16}$

The 'time is out of joint' also in Gramsci's reflections on relations between urban centres and their rural 'peripheries', a significant theme in his study of the experience of the Risorgimento, modern Italian state formation, and particularly the role of different types of intellectuals in these processes. The metropolitan (or sometimes even simply 'provincial') present may take pride in discovering a stereotypical image of its 'past' in its rural hinterland (e.g., Q1, §43, 34-40) In reality, it encounters in these dislocations alternative temporal organisations that its own relations of force both produce and deny, as a self-proclaimed standard of contemporaneity that structurally requires 'examples' of the non-contemporary in order to secure its own dominance. One important dimension of 'Some Aspects of the Southern Question' is constituted precisely by the attempt to analyse such forms of 
‘imposed anachronism’ as the opportunity for a political intervention (Gramsci 1994, particularly 320).

Above all, the Prison Notebooks theorize non-contemporaneity as a hegemonic relation. As a theory of political leadership [direzione], ${ }^{17}$ hegemony presupposes the multiple times of uneven socio-political development both within national social formations and internationally. This is not simply the noncontemporaneity of the relations between supposedly 'advanced' social forces (for example, of an urban proletariat) proposing to lead social groups still mired in seemingly 'anachronistic' social relations (a rural peasantry) along the uneven and contradictory path of 'modernization'. ${ }^{18}$ Gramsci inherited such a conception of hegemony as a 'leveraging' of temporal distinctions from the debates of Russian Social Democracy and the early years of the Third International, reflecting on their implications both before and throughout the Prison Notebooks. It is also, and perhaps even more importantly for Gramsci’s distinctive conceptualisation of hegemony as a political practice, a question of the multiple times, rhythms and durations implicit in hegemony as a 'pedagogical relationship', that is, as a dynamic relation between 'leaders and led’ (Q10II, §44, 1331), or between the instance of programmatic proposal and the organisational practices that are elaborated and modified in the ongoing relations of translation between theory and practice. It is only in the perspective of constitutive and enduring temporal distinctions that hegemony or leadership can be understood as a process of constructing historical 'progress' as a concrete political act, rather than predetermined (and determining) goal ultimately reducible to a static sovereign instance.

In each of these cases, the present is conceived as constitutively composed of multiple 'times' that are not contemporaneous with each other. This is not, however, a 
model of the simultaneity of diverse times conceived in terms of the survival of anachronisms within what remains, 'in the last instance', a unitary present: a 'contemporaneity of the non-contemporaneous', in one of senses in which Koselleck uses the phrase, of the presence 'in the same time' of elements that originated in diverse historical moments (Koselleck 2000, 9). More radically, Gramsci draws attention to the 'production of the "past" within the present', of the active temporal and political subordination of some practices to the times, rhythms and priorities of others. ${ }^{19}$ Gramsci’s discussion of the relationship between national languages and dialects, for instance, does not analyse them in terms of hierarchical relations of degeneration or purity, as if dialects merely represented a 'fossil' from a previous stage of the national language’s development (see, e.g., Q1, §73, 81; Q3, §73, 350; Q6, §71, 738; Q11, §12, 1376; Q14, §15, 1671). Rather, they are seen as a function of the different rhythms and temporal organizations linked to the conditions of political subalternity or hegemonic direction shaping the communities of their practitioners. 'Dialects' are thus ultimately not seen as 'residues of the past', but as actively produced and reproduced in and by the present, as the practices of some linguistic communities are retrospectively defined in the ongoing (and interminable) process of formation of modern national languages as ‘their' dialects.

Rather than being expressive of an essence equally present in all practices, the present for Gramsci is therefore an ensemble of those practices in their different temporalities, a continual interweaving of many different times. Any unity of those different times remains always provisional, and must be imposed (often, violently) against their constitutive plurality. The contemporaneity of the present, that is, is not thought as a point on a linear continuum, a spatial coordinate, or an archaeological layer, but as a politically constructed relation. Precisely as a relation, it thus cannot be 
comprehended with the topological metaphor of a 'structure', as a totalised hierarchy of elements whose relation is fixed by the totality prior (either chronologically or logically) to the dynamic of their relationality itself.

\section{The 'ruse' of structure}

Nevertheless, even if Gramsci can be regarded as a preeminent thinker of temporal dislocations and non-contemporaneity, does he thereby avoid the most disabling of the consequences of an expressivist and essentialist notion of the present, of the 'ideology of a homogenous-continuous/self-contemporaneous time' (Althusser and Balibar 1970, 106)? A model of plural times, in itself, does not necessarily provide immunity against the complement of an essentialist notion of the present, or against its logical fulfilment: namely, the depiction of the social whole as an ordered field, whether produced by an originary determination or retrospective transcendental comprehension. Similarly, a ‘spatialization' of multiple ‘times', of either a two dimensional cartographical or a three dimensional archaeological model, does not on its own prevent the reconstitution of the notion of an 'essential section' of the coordinates of each particular moment of the field's historical existence; in certain 'metastructural' formulations, a theory of multiple times may actually even presuppose such a theory of periodization. In this case, the plural times would be defined as 'plural' precisely due to their divergent positioning in and by the structure (of any given present, or 'period') or metastructure (of history itself), which would function as their unifying measure. ${ }^{20}$ In other words, these plural times would ultimately be ordered by a common measure of a 'structure' in which their plurality is localised and constituted as a plurality within this unity. 
Furthermore, as we have seen, according to Althusser's argument there is an integral link between an 'ideological conception of historical time’, a spiritualist notion of the social totality, and the notion of politics as a clash between subjects, conceived as competing claims to embody the adequate self-comprehension of the present and thereby 'to complete' it. Does Gramsci avoid the depiction of politics as a struggle between subjects on the unifying terrain of the present, conceived as such a temporal structure-object? That is, although he rarely used the explicit vocabulary of the concept of the subject from the history of modern philosophy, was Gramsci nevertheless implicitly and perhaps unwittingly operating within the philosophical grammar of knowing and doing subjects struggling to demonstrate the authenticity of their claims of mastery of the 'object' of the social formation? ${ }^{21}$ In this case, plural temporalities might be understood as merely a ruse on the way to the reconstitution of a more fundamental and singular measure: namely, the present conceived as a structure traversed by plural times that find their telos in the conflictual formation of a subject capable of uniting them, comprehending the complexity of their articulation as a structure-object, and providing them with a consciousness of themselves.

\section{Prediction, Foresight, 'Prevision’}

The Prison Notebooks undoubtedly contain formulations that could be used to support positive responses to these interrogatives, particularly those passages that seem to propose a progressive unification of plural times in a radically new 'present', one that is not given, but to be 'achieved' in the historical process. For instance, Gramsci's notion of the coming into being of a 'regulated society', his emphasis upon the stages in the process of formation of 'collective wills', and the frequent references to 
'historical progress' in the Prison Notebooks can all be read as pointing towards a process of development, synchronization and unification of multiple times, currently split and divided in class society but to be 'redeemed' in the unified future of a communist society (see, e.g., Q6, §65, 734; Q6, §88, 763-4; Q7, §33, 882). From Togliatti and the post-war PCI's notion of a 'progressive democracy' to Ernesto Laclau and Chantel Mouffe's conception of the construction of a chain of equivalence and ultimately a political subject, hegemony has frequently been read as implying such a unification of the diverse, or even to be the mechanism of its realization. ${ }^{22}$ My thesis is that such understandings of the temporal dimensions of hegemony can be problematized by attending to the progressive development of a distinctive notion of 'previsione' in the Prison Notebooks, particularly from May 1932 onwards. ${ }^{23}$ This word and the related prevedibilità and prevedere have been variously rendered by Gramsci’s English translators as ‘prediction’, ‘predictability’ and 'to predict', on the one hand, and 'foresight', 'foreseeability' and 'to foresee', on the other. ${ }^{24}$ The former translation, emphasising the largely logico-inductive senses with which prediction is usually associated in English, captures one dimension of common uses of the Italian word, and seems particularly appropriate to render Gramsci’s objections to Bukharin’s conception of science in Q11 (see, e.g., Q11, §15, 1403-6; Q11, §26, 1431), or to Croce’s critique of Marx’s notion of the tendential fall of the rate of profit (e.g., Q10II, §33, 1279; Q10II, §36, 1281). The latter translation, on the other hand, has the benefit of highlighting the strongly sensual and visual dimension of some of Gramsci’s reflections, particularly evident in notes discussing the possibility of knowledge of the future (e.g., Q7, §25, 874; Q4, §86, 527-8), folkloric conceptions prophecy (Q4, §85, 527), and Croce’s critique of Limentani (Q13, §1, 1557; Q10II, 41, §1311). Both translations have the further advantage of 
allowing a consistent translation of all cognates throughout the Prison Notebooks.

What both translations run the risk of occluding, however, is the way in which Gramsci's use of this word is traversed by a tension between both of the senses united in the Italian word (logico-inductive and visual), almost as if he were aiming to contest and problematize each 'model' of previsione by setting it against the other. This tension becomes particularly acute in May 1932, when he discusses Croce’s critique of Ludovico Limentani’s attempt to develop a coherent positivist theory of the 'previsione dei fatti sociali’ (Q13, §1, 1557; see also Q10II, 41, §1311, from JuneDecember 1932). From this point on, words from this group are frequently placed in problematizing quotation marks, one of the forms in which Gramsci habitually emphasised his appropriation and problematization or transformation of received concepts and words (see, e.g., Q11, §15, 1403;Q11, §26, 1432; Q11, §52, 1477; Q15, $\S 50,1811) .{ }^{25}$ In order to emphasise this dynamic development, I therefore propose to use the less common (in current English) and more literal (from the Italian) translation of 'prevision' for the translation of those notes where this contestation and problematization is decisive, reserving 'prediction' and 'foresight' (and other variants) for the notes in which those other senses seem to me to be predominant. Although this has the disadvantage of not easily allowing a consistent and recognizable translation of cognates (and thus requiring the provision of the original Italian word in parentheses), ${ }^{26}$ it does direct attention to the extent to which Gramsci in 1932 develops a distinctive, new conception of prevision that is irreducible either to the models of inductive reasoning that inform most notions of prediction, or to the temporal linearity presupposed by common notions of foresight, conceived as seeing further into the future (in this sense, overlapping with notions of prophecy).

Gramsci’s research here undergoes a development in which models of pro- 
and anachronistic time are problematized by the positing of constitutive noncontemporaneity as the determining dynamic of any apparently achieved present. Prevision in this sense is understood neither as a form of 'prediction' of the future predicated on the past, nor as a type of prefigurement of the future in the graven images of the present. It is not, that is, a question of the type of mental ability 'to foresee’ or 'to see before’ [prooráō] the future that, for Aristotle, founds the master's 'natural' dominance over the instrumentalized slave (Aristotle, Pol. I. 1252a32-35), or the 'presentiment' that Althusser characterised as the way in which, for Hegel, 'great men' 'divine' the future, rather than 'perceive' or 'know' it (Althusser and Balibar 1970, 95). Even less is it posited as a response to the problem of transition, where change would be thought through relapse to a linear temporal model, with the sighting of the new on the far off horizon of the present, in the sense of a hermeneutical Erwartungshorizont. In a certain sense, 'pre-vision' is not thought as a form of 'vision' at all, but rather, as that which comes before vision, as its condition of

possibility, or that which allows the present to be seen differently. ${ }^{27}$ In this sense, prevision is conceived more as a construction or as an 'intervention', as the modification of existing rhythms and tempos of discordant times, and the 'weaving' of a new composition of the irreducible plural temporalities that denies the selfidentity of a synchronizing present.

\section{'Prevision' as a 'method' of political work}

The 'non-presence of the present' was a visceral theme for the imprisoned and increasingly isolated Gramsci, prompting him to reflect intensely on the tragedy of Cavalcanti in Canto X of Dante’s Inferno. Cavalcanti ‘sees into the past and sees into 
the future, but does not see into the present, in a determinate zone of the past and of the future in which the present is located' (Q4, §78, 517; May 1930). ${ }^{28}$ In May 1932, the series of notes on Dante are explicitly linked to the theme of the 'gift of foresight' [il dono della previsione] or the 'foresight of the damned' [la previsione dei dannati] (Q4, §85-§86, 527-8), even suggesting a prophetic capacity (particularly in Q4, §85, 527, with a reference to the classical figure of Cassandra). As so often in the Prison Notebooks, engaging with Croce provides Gramsci with a foil for the further development of his own thoughts. This occurs in a seemingly marginal way in the same period in the first note of notebook 13 (Q13, §1, 1557; also from May 1932) when Gramsci briefly refers to a review by Croce of Limentani’s La previsione dei fatti sociali (Limentani 1907). This text seems to have a significant impact on Gramsci thinking in this period, which witnesses a number of important explicit and implicit references both to Croce's review itself and the relevance of the concept of previsione for understanding Croce's thought more in general. ${ }^{29}$

Originally published in La Critica in 1907, later republished in Croce’s Conversazioni critiche (Serie prime) in 1918 (the edition to which Gramsci refers), Croce had objected to Limentani's book in highly dismissive terms. The etymology of prevedere itself (deriving from the conjunction of the Latin prae - before - and videre - to see), Croce argued, already condemned any attempt to develop a coherent theory of its application in the social field. ${ }^{30}$

The first condition in order to see [vedere] (that is, to know) a fact is that it has happened, that is, that the fact is. To speak of the possibility of foreseeing [prevedere] therefore seems an empty discourse, about something that is contradictory by definition and according to 
etymology’ (Croce 1907, 235).

He continued by arguing that in a strict sense there could be no genuine knowledge of the future, because all knowledge by definition was a knowledge of the present.

What we call foreseeing [prevedere] is nothing but an imaginative and emphatic mode for expressing not the future - of which we know and can know nothing and which is not material of knowledge - but the present: it is therefore not a foreseeing [pre-vedere], but a seeing [vedere] (ibid).

Gramsci argues that Croce's position not only effectively denies the possibility of any form of knowledge of the future, but also of a rational theory of historical transformation. Thus, in late 1932, objecting to Croce’s depiction of Marx’s theory of value as an invalid ‘elliptical comparison’, Gramsci argues that Croce’s concept, applied in the field of history, would imply a dogmatic distinction between past and future and make both historical development and history itself unthinkable: 'history is an implicit comparison between the past and the present [...] And why is ellipsis illegitimate when one makes a comparison with a hypothesis about the future, whereas it is legitimate when one makes a comparison with a past fact?' (Q 10II, §41, 1310; August-December 1932; see also Q7, §42, 891; November 1931). Croce’s perspective, Gramsci argues, in fact involves an elliptical comparison that eternalises a particular concept of the present, reduced to the repetition of its historical determinants: a conservative conception in which 'foresight is nothing more than a special judgement on the present’ (Q10II, §41, 1311; August-December 1932; see 
also Q15, §36, 1790; May 1933).

These reflections prepare Gramsci for his engagement with Bukharin, in whom he finds an equally abstract mode of posing the problem, according to an effectively mechanical conception of prediction. A teleological linear conception of historical time is argued to underlie Bukharin's supposed 'search of essential causes, indeed, for the "first" cause, for the "cause of causes"', sought in order 'to guarantee' predictions regarding future developments. Such an attempt 'to resolve in peremptory fashion the practical problem of the predictability [prevedibilità] of historical events' (Q11, §15, 1403; July-August 1932) presupposes 'criteria constructed on the model of the natural sciences’ (Q11, §26, 1432; July-August 1932), which misapprehend, Gramsci later argues, the experimental nature of modern scientific practice (see Q15, $\S 50$, 1811; May-June 1933). Bukharin’s invocation of Marxism as a sociology, in particular, prompts Gramsci to object that such a notion of sociology is an attempt 'to derive "experimentally" the laws of evolution of human society in such a way as to “predict” [prevedere] that the oak tree will develop out of the acorn’ (Q11, §26, 1432; July-August 1932; see also Q11, §15, 1404).

Above all, it is in the critique of political economy that Gramsci finds the outlines for a notion of previsione that begins to break with a temporal linear model, even while remaining tied to a proto-structuralist, 'synchronic' conception of the social totality. His reflections in late 1932 on the philosophical significance of Ricardo's contribution to the delineation of a non-metaphysical notion of immanence play a particularly important role in this development. In this conception, 'necessity' is understood 'in an "historical-concrete” sense', rather than 'speculative-abstract', as the presence of 'an efficient and active premise' that becomes 'operative' in a calculation of means and ends (Q11, §52, 1477; August-December 1932). Central 
here is what Gramsci calls the 'concept and fact of "determinate market”'. He glosses this as

the scientific revelation that determinate decisive and permanent forces have arisen historically, the operation of which presents itself with a certain 'automatism' that allows a measure of 'predictability' [prevedibilità] and certainty for the future of individual initiatives [...]. 'Determinate market' is therefore equivalent to saying 'determinate relation of social forces in a determined structure of the productive apparatus', a relation guaranteed (that is, rendered permanent) by a determinate juridical, moral and political superstructure (Q11, §52, 1477; August-December 1932; see also Q8, §128, 1018; April 1932).

This perspective, strongly focused on structural determination, repetition and duration, is tempered by Gramsci's forging in the same period (in his research into a praxis-oriented alternative to 'objectivist' conceptions of scientific knowledge) of a relation between previsione and political programme. The decisive moment in the development of Gramsci's distinctive concept comes when it is no longer linked to temporal models of prefiguration or spatial models of localization. Instead, Gramsci emphasises the operative dimensions of 'prevision' as an intervention into the current intertwinings of plural times, as a mode of construction. He argues that 'in reality one has a "prevision" [si "prevede"] to the extent that one acts, to the extent that one applies a voluntary effort and therefore contributes concretely to creating' the conditions of the prevision (Q11, §15, 1403; July-August 1932). 'Prevision thus 
proves to be', he argues, 'not a scientific act of knowledge, but the abstract expression of the effort that is made, the practical mode of creating a collective will' (ibid).

In mid 1933, in the midst of Gramsci’s 'mature’ reflections on Machiavelli, this perspective is consolidated and theorized explicitly. ${ }^{31}$ Prevision is here formulated as a dimension of the notion of 'programme', as the active organisation of given relations in order to 'make victorious' a particular 'prevision'; echoing Gramsci’s earlier analysis of Machiavelli’s distinctive political realism, such a practice of prevision is regarded as itself potentially becoming a decisive 'element of such victory’ (Q15, §50, 1810; May-June 1933). ${ }^{32}$ In other words, this notion of prevision involves an active process of construction, of new relations of force that are capable of modifying the existing relations. Rather than the subsumption of the contradictions of the present in a projected unified future, the political practice of prevision instead posits the emergence of a distinctive time alongside and within the other existing plural times: the time of the intervention of an alternative. ${ }^{33}$ 'The time is out of joint' precisely at the moment when it is unhinged by an intervention within and against the 'accomplished' present, when alternative forms of relationality challenge the notion of a possible unifying synchronisation itself. Rather than simply negating that particular present in order to affirm another, the act of prevision instead actively undermines the notion of the present itself, highlighting the impossibility of its self-identity and self-presence, because always fractured by the possibility of alternative relationalities. Nicola Badaloni has aptly described this as

a method of 'prevision' in determinate conditions, some of which are not 'given', but are constructed, or are able to be constructed, by means of the organisation, practice and formation of models of reality that are 
capable of disaggregating what had at first sight seemed dominated by a completely unchangeable necessity or causal order (Badaloni 1981, 335).

Such a method of prevision does not envisage a moment in which the present could finally become identical with itself, with the arrival of a political subject capable of synchronising its conflicting times in an 'authentic' form. ${ }^{34}$ Rather, prevision as a method of political work presupposes the continuing existence of multiple times; it emerges precisely as a distinctive relation to the plurality of those times, which it aims to modify through the construction of alternatives modes of their intertwining. It is this method of political work, of the fracturing of the time of the present by the counter-times of alternative forms and practices of organisation, that is designated by the name of hegemony.

\section{Conclusion}

Althusser’s outline for a concept of historical time helped to re-open the Marxist tradition to an engagement with the themes of temporal diversity and plurality. In his early work, he aimed to theorize how temporal dislocations could be thought as constitutive relations, rather than as actions of a determining structure or expression of subjective experiences, and on this basis took his distance from the seemingly all too ‘Hegelian’ Gramsci. Provisionally presented in Reading Capital as a challenge for further elaboration, Althusser's 'flirtation’ with structuralist concepts not only compromised his critique of formalism, but also tended to re-introduce the spectre of temporal synchronization. Furthermore, his later research's overdetermination by the 
return of a theory of the subject prevented him from coherently elaborating the full implications of his initial formulations, particularly in terms of their relevance for a theory of revolutionary politics.

Paradoxically, Gramsci can today be read as offering a resolution to Althusser's aporiai. The Prison Notebooks' insistence on constitutive noncontemporaneity enabled Gramsci to elaborate a consistently relational theory of temporal plurality, without recourse to the philosophical grammar of the subject. As a

method of political work, Gramsci’s notion of prevision represents a mode of political intervention that valorizes the non-presence of the present, not as a problem to be overcome, but as the enduring condition and enabling challenge of hegemonic politics. It is perhaps in the process of constructing historical 'progress' as such a concrete political act, of temporal organizations that constitute an alternative to the dominant order's claims to embody 'the present', that we may discern the outlines for a genuinely 'post-Hegelian politics'.

\section{References}

Althusser, L. 1969. For Marx. London: NLB.

Althusser, L. 1971. Lenin and Philosophy and Other Essays. Trans. B. Brewster. New York: Monthly Review Books.

Althusser, L. 2003. On Lévi Strauss. The Humanist Controversy and Other Writings 1966-67. London: Verso. 
Althusser, L. 2006. Philosophy of the Encounter: Later Writings 1978-1987, ed. François Matheron, trans. G.M. Goshgarian, London: Verso.

Althusser, L. 2007. Montesquieu: Politics and History. Politics and History: Montesquieu, Rousseau, Marx. London: Verso.

Althusser, L. and Balibar, É. 1970. Reading Capital. London: NLB.

Aristotle 1932. Politics, tr. H. Rackham. Cambridge (Mass.): Harvard University Press.

Badaloni, N. 1981. Antonio Gramsci. La filosofia della prassi come previsione, in Storia del marxismo Vol. III—Il marxismo nell'eta' della terza internazionale. ed. E. J. Hobsbawm et al., Turin: Einaudi.

Balibar, É. 2003. Structuralism: A Destitution of the Subject? Differences: A Journal of Feminist Cultural Studies 14(1): 1-21.

Bensaïd, D. 2002. A Marx for Our Times. Adventures and Misadventures of a Critique. London: Verso.

Bevernage, B. 2016. Against Coevalness: A Belated Critique of Johannes Fabian’s Project of Radical Contemporaneity and a Plea for a New Politics of Time. Manuscript, Anthropological Theory (forthcoming). 
Bloch, E. 1991. The Heritage of Our Times, trans. N. \& S. Plaice. Cambridge: Polity.

Buci-Glucksmann, C. 1980 [1975]. Gramsci and the State. London: Lawrence and Wishart.

Cesare, C. and Negri, A. 2008. In Praise of the Common: a Conversation on Philosophy and Politics. Minneapolis: University of Minnesota Press.

Chakrabarty, D. 1998. Minority Histories, Subaltern Pasts. Postcolonial Studies 1(1): $15-29$.

Chambers, S.A. 2011. Untimely politics avant la lettre: The temporality of social formations. Time and Society 20(2): $197-223$.

Coassin-Spiegel, H. 1997 [1983]. Gramsci und Althusser. Eine Kritik der Althusserschen Rezeption von Gramscis Philosophie. Hamburg-Berlin: Argument.

Cospito, G. 2011. Il ritmo del pensiero. Per una lettura diacronica dei ‘Quaderni del carcere’ di Gramsci. Naples: Bibliopolis.

Coutinho, C.N. 2009. Rapporti di forza, Dizionario gramsciano 1926-1937, eds G. Liguori and P. Voza. Rome: Carocci. 
Crezegut, A. 2016. Althusser, étrange lecteur de Gramsci. Lire « Le marxisme n’est pas un historicisme »: 1965-2015. Décalages 2(1).

Croce, B. 1907. Review of Limentani, La previsione dei fatti sociali. La Critica. Rivista di Letturatura, Storia e Filosofia 5:235-6.

Derrida, J. 1972. Positions. Paris: Les Editions de Minuit.

Freitas-Branco, J.M. de. 2001. Gegenstand. Das historisch-kritische Wörterbuch des Marxismus Bd. 5, ed. W.F. Haug. Hamburg-Berlin: Argument.

Frosini, F. 2010. La religione dell'uomo moderno. Politica e verità nei Quaderni del carcere di Antonio Gramsci. Rome: Carocci.

Goshgarian, G.M. 2003. Introduction, in The Humanist Controversy and Other Writings 1966-67. London: Verso.

Goshgarian, G.M. 2012. The very essence of the object, the soul of Marxism, and other singular things: Spinoza in Althusser 1959-67. Encountering Althusser. Politics and Materialism in Contemporary Radical Thought, eds K. Diefenbach, G. Kirn, S.R. Farris and P.D. Thomas. New York: Bloomsbury.

Gramsci, A. 1957. The Modern Prince and Other Writings, tr. L. Marks. New York: International Publishers. 
Gramsci, A. 1971. Selections from the Prison Notebooks, ed. and trans. Q. Hoare and G. Nowell-Smith. New York: International Publishers.

Gramsci, A. 1975. Quaderni del carcere. Turin: Einaudi.

Gramsci, A. 1993. Letters from Prison, 2 Volumes, ed. F. Rosengarten, tr.R. Rosenthal. New York: Columbia University Press.

Gramsci, A. 1994. Pre-Prison Writings, ed. R. Bellamy. Cambridge: Cambridge University Press.

Gramsci, A. 1995. Further Selections from the Prison Notebooks, ed. and trans. D. Boothman. London: Lawrence \&Wishart.

Gramsci, A. 1996. Prison Notebooks, Volume 2, ed. and tr. J. A. Buttigieg, New York: Columbia University Press.

Gramsci, A. 2007. Prison Notebooks, Volume 3, ed. and tr. J. A. Buttigieg, New York: Columbia University Press.

Hallward, P. 2012. Theoretical Training. Concept and Form, Volume 1, Selections from The Cahiers pour l'Analyse, ed. P. Hallward and K. Peden. London: Verso.

Harootunian, H. 2015. Marx after Marx: History and Time in the Expansion of Capitalism. New York: Columbia University Press. 
Haug, W.F. 2006 [1996]. Philosophieren mit Brecht und Gramsci. Hamburg-Berlin: Argument.

Hindess, B. 2007. The Althusserian moment and the concept of historical time. Economy and Society 36(1): 1-18.

Jordheim, H. 2012. Against Periodization: Koselleck’s Theory of Multiple Temporalities', History and Theory 51: 151-71.

Jordheim, H. 2014. Introduction: Multiple Times and the Work of Synchronization. History and Theory 53: 498-518.

Koivisto, J. and Lahtinen, M. 2012. Conjuncture. Historical Materialism 20(1): 2677.

Koselleck, R. 2000. Zeitschichten. Frankfurt/M: Suhrkamp.

Kouvelakis, S. 2003. Philosophy and Revolution. From Kant to Marx. London: Verso.

Laclau, E. 2006. Why Constructing a People is the Main Task of Radical Politics. Critical Inquiry 32(4), 646-80.

Laclau, E and Mouffe, C. 1985. Hegemony and Socialist Strategy: Towards A Radical Democratic Politics. Trans. W. Moore and P. Cammack. London: Verso. 
Limentani, L. 1907. La previsione dei fatti sociali. Turin: Fratelli Bocca, Editori.

Marx, K. and Engels, F. 1978. Werke Bd 3. Berlin: Dietz.

Miller, J.-A. 2012. Action of the Structure. Concept and Form, Volume 1, Selections from The Cahiers pour l'Analyse, ed. P. Hallward and K. Peden. London: Verso.

Montag, W. 2013. Althusser and his Contemporaries. Philosophy's Perpetual War. Durham: Duke University Press.

Morfino, V. 2009. Spinoza e il non contemporaneo. Verona: Ombre corte.

Morfino, V. 2014. Plural Temporality. Transindividuality and the Aleatory between Spinoza and Althusser. Leiden: Brill.

Osborne, P. 1995. The Politics of Time: Modernity and Avant-Garde. London: Verso.

Pradelle, D. 2004. Gegenstand/Objekt. Vocabulaire Européen des Philosophies:

Dictionnaire des Intraduisibles, ed. B. Casin. Paris: Editions du Seuil.

Ragazzini, D. 2002. Leonardo nella società di massa. Teoria della personalità in Gramsci. Bergamo: Moretti Honegger. 
Rosengarten, F. 1986. Gramsci’s “Little Discovery”: Gramsci’s Interpretation of Canto X of Dante’s Inferno. Boundary 2, 14(3): 71-90.

Rossi, A. and Vacca, G. 2007. Gramsci tra Mussolini e Stalin. Rome: Fazi editore.

Schöttler, P. 1993. Althusser and Annales Historiography. An Impossible Dialogue? The Althusserian Legacy, eds E. A. Kaplan and M. Sprinkler. London: Verso.

Sotiris, P. 2014. How to Make Lasting Encounters: Althusser and Political Subjectivity. Rethinking Marxism 26(3): 398-413.

Suchting, W. 1997. Empirismus. Das historisch-kritische Wörterbuch des Marxismus Bd. 3, ed. W.F. Haug. Hamburg-Berlin: Argument.

Thomas, P.D. 2009. The Gramscian Moment. Philosophy, Hegemony and Marxism. Leiden: Brill.

Thomas, P.D. 2017. The Modern Prince: Gramsci’s Reading of Machiavelli. History of Political Thought 38(1).

Tomba, M. 2011. Strati di tempo. Karl Marx materialista storico. Milan: Jaca Books.

Tombazos, S. 1995. Les temps du capital, Paris: Cahiers des saisons. 
Tosel, A. 1995. In Francia. In Gramsci in Europa e in America, edited by E.J.

Hobsbawm. Rome-Bari: Laterza.

Urbinati, N. 1998. From the Periphery of Modernity: Antonio Gramsci's Theory of Subordination and Hegemony. Political Theory 26(3): 370-91.

Zammito, J. 2004. Koselleck’s Philosophy of Historical Time(s) and the Practice of History. History and Theory 43: 124-35.

\footnotetext{
${ }^{1}$ References to Gramsci’s Prison Notebooks [Quaderni del carcere] follow the internationally established standard of notebook number (Q), number of note (§), followed by page reference to the Italian critical edition (Gramsci 1975). The English critical edition of the Prison Notebooks, edited by Joseph A. Buttigieg, now comprises three volumes (Gramsci 1992, 1996, 2007), containing Notebooks 1-8; notes included in those volumes can be located according to the notebook and number of note.

${ }^{2}$ The notions of 'times' and 'temporalities' are used interchangeably throughout this text, following Althusser's usage in Reading Capital, though there a strong arguments and precedents for distinguishing more strictly between them.
}

${ }^{3}$ See also Althusser’s discussion of the “"dislocation” (décalage) and torsion of the different times and temporalities produced by the different levels of the structure, the complex combination of which constitutes the peculiar time of the process's development' (Althusser and Balibar 1970, 104).

${ }^{4}$ For a survey of different meanings of the notion of 'conjuncture' in modern political and social thought that emphasis this active sense, see Koivisto and Lahtinen 2012.

${ }^{5}$ This unintended return of a structuring totality was perhaps the most disabling consequence of Althusser's flirting with structuralist terminology, noted by Macherey at the time; for an incisive discussion of their exchanges, see Montag 2013, 75 et sqq.

${ }^{6}$ On the early Althusser's critique of formalism (as an instance of the determination of the particular by a purported 'universal'), see in particular Althusser 2003 and 2007. For critical discussion of its importance for all of his thought, see Goshgarian 2003, xliii et sqq. and Montag 2013, 68-70). 
${ }^{7}$ For instance, Derrida noted on a number of occasions his critical agreement with some aspects of Althusser's theory of historical time, particularly its emphasis upon a plurality of histories; see, e.g., Derrida 1972, 79.

${ }^{8}$ Contemporary discussions of plural or multiple times have been heavily influenced by Koselleck’s approach, relatively rarely considered in terms of its potential productive relations with Althusser’s. On Koselleck’s notion of multiple times, see Zammito 2004 and Jordheim 2012, and on connections between Althusser and Koselleck, Bevernage 2016.

${ }^{9}$ Althusser not only took his distance from structuralism in his self-critique in the late 1960s and early 1970s, but, as recent research has emphasised, was openly criticising it from the early 1960s. He 'had been decrying structuralism, “idealism’s last hope”, as a philosophical fraud since his 1962-63 seminar on the subject’ (Goshgarian 2003, xii).

${ }^{10}$ Previous materialism, Marx argued, conceived of the 'the object, actuality, sensuousness [der Gegenstand, die Wirklichkeit, Sinnlichkeit]' 'only in the form of the object or of contemplation [nur unter der Form des Objekts oder der Anschauung], but not as human sensuous activity, praxis'. Feuerbach’s attempt to posit objects [Objekte] that are really distinct from thought-objects [Gedankenobjekte] is judged to fail because he does not conceive 'human activity itself [die menschliche Tätigkeit selbst] as objective activity [gegenständliche Tätigkeit]' (Marx and Engels 1978, 5). Unlike the indistinct usage of the couplet Gegenstand/Objekt in Kant, Marx here appears to distinguish between them, ascribing to the concept of Objekt the role of a formal comprehension of the theory-praxis nexus that would seemingly be more adequately grasped by the active dimensions of the concept of Gegenstand. As João Maria de Freitas-Branco (2001) argues, Marx’s subtle and oftenneglected terminological innovation plays a decisive role in the development of 'an entirely new type of materialist and dialectical gnoseology’. Regarding Kant’s use of the terms, see Pradelle 2004.

${ }^{11}$ For a representative example of this reading, see Osborne 1995. If, as Hindess (2007) suggests, the aim of Althusser's early project was to provide a consistently anti-essentialist theory of social whole, the problem of transition (from point A to point B) itself might be argued to presuppose precisely the type of 'structuralist' spatialization that Althusser's emphasis upon articulation (that is, relationality, or in the terms Althusser himself used, 'differential') attempted to overcome (Althusser and Balibar 1970, 100). See also Chambers 2011. 
${ }^{12}$ Arguably, the multiple recent returns to different notions of a 'non-essentialist' subject in postAlthusserianism, from Butler to Badiou to Balibar, have effectively followed Althusser's own turn to notions of the ideological constitution of a subject-function in the late 1960s, following the rebuffing of his original anti-humanist offensive in the PCF. See Goshgarian 2003 and Sotiris 2014. For a discussion of the theoretical context of the 'return of the subject' in 1960s French philosophy, see Hallward 2012.

${ }^{13}$ For this reason, the early Althusser should be distinguished from what Balibar has described as a ‘typical movement of structuralism', insofar as he offered the possibility for thinking a 'deconstruction' of the (category of the) subject that would not be simultaneously a 'reconstruction of the subject' (Balibar 2003, 10).

${ }^{14}$ On the specificity of Althusser's concept of empiricism, see Suchting 1997.

${ }^{15}$ For critiques of Althusser's reading of Gramsci, see Buci-Glucksmann 1980; Tosel 1995, 5-26; and Coassin-Spiegel, 1997; Haug, 2006; Thomas 2009. For a detailed historical contextualisation of Althusser's early reading of Gramsci, see Crezegut 2016. For a recent argument that the concept of uneven development plays a much more prominent role in Hegel's account of historical time than Althusser supposed, see Hindess 2007.

${ }^{16}$ Gramsci's writings in the period leading up to a profound crisis of his health in March 1933 contain several significant reflections on the constitutively conflictual temporal formation of the person. See in particular Q15, §9, 1762-4, where he articulates these reflections with his notion of 'molecular' composition, and his letter to Tania of 6 March 1933 (Gramsci 1993, Volume 2, 278).

${ }^{17}$ On the importance of the notion of political leadership in Gramsci's notion of hegemony, see Cospito 2011, 122-6.

${ }^{18}$ Traces of such a conception of non-contemporaneity are present in Boch's attempt to analyse the temporal conditions of Nazism; see Bloch 1991, particularly 97-148.

${ }^{19}$ This conception of 'multiple presents' could be fruitfully compared to Chakrabarty's notion of 'subaltern pasts’ (1998). See in particular Q11, §12, 1376.

${ }^{20}$ As I have previously suggested, this was one of the risks run by Althusser's 'flirtation' with structuralist terminology, particularly regarding the formulation of the concept of a mode of production. For an attempt to read Koselleck's work as such a theory of periodization, see Osborne 
1995, 9-13. For alternative views of the import of Koselleck’s metaphor, see Zammito 2004, Jordheim 2012 and particularly Jordheim 2014.

${ }^{21}$ On the extent to which Gramsci’s thought cannot be comprehended in terms of a philosophical theory of the subject (conceived in the classical terms of introspection, self-consciousness, intentionality or authorship), see Frosini 2010, 28-9.

${ }^{22}$ Bevernage (2016) attempts to formulate Laclau and Mouffe's theory in temporal terms, focusing in particular upon a politically constituted hegemonic coevalness, or coevalness 'effect'. Laclau 2006 contains the fullest statement of the formalist dimensions of Laclau's notion of 'the people' as a political subject. Negri has argued for the continuities between Laclau and Mouffe’s interpretation of hegemony and that of Togaliatti and the postwar PCI (Casarino and Negri 2008, 162-4).

${ }^{23}$ On the development of the concept of prevision in Gramsci, see Badaloni 1981.

24 'Prediction' was mostly preferred, with some exceptions, by Hoare and Nowell-Smith (in Selections from the Prison Notebooks, Gramsci 1971) and Boothman (Further Selections from the Prison Notebooks, Gramsci 1995); see Gramsci 1971, 363 (Q10II, §50, 1341); 127 (Q13, §1, 1557); 438 (Q11, §15, 1403-6); 368 (Q10II, §40, 1291); 410 (Q11, §52, 1477); 169-171 (Q15, §50, 1810); and Gramsci 1995, 418 (Q10II, §11, 1249); 429 (Q10II, §33, 1279); 465 (Q10II, §14, 1250-3). Marks (The Modern Prince, Gramsci 1957) and Buttigieg (critical edition of the Prison Notebooks, Gramsci 1996 and 2007), on the other hand, propose 'foresight’; see Gramsci 1957, 101 (Q11, §15, 1403); 161-2 (Q15, §50, 1810); Gramsci 1996, 256 (Q4, §85-§86, 527-8); and Gramsci 2007, 176 (Q7, §25, 874); 372 (Q8, §225, 1083). On one occasion Buttigieg employs the variant ‘farsightedness’; see Gramsci 2007, $342(Q 8, \S 185,1053)$.

${ }^{25}$ On Gramsci’s use of a ‘philology of quotation marks’, see Ragazzini 2002, particularly 17.

${ }^{26}$ My translation choice in this sense freely signals its status as a particular interpretation or reading, subject to the contestability of any interpretation; it will have served its purpose if it forcefully highlights the novelty of this development in Gramsci’s vocabulary.

${ }^{27}$ Gramsci's conception of prevision thus reverses the relation of 'non-vision' (or 'oversight') and 'vision’ in Althusser’s critique of the shared presuppositions of the 'empiricist conception of knowledge' (as a process of abstraction or even 'extraction') and the 'religious vision of the essence'; rather than 'inside vision' and thus determined by what it already sees, prevision precedes it and in certain conditions makes it possible. See Althusser and Balibar 1970, 19, 21, 25, 35-7. 
${ }^{28}$ On the aesthetic and philosophical significance of Gramsci’s 'little discovery’ in Dante studies, see Rosengarten 1986. On the political significance of these studies, particularly regarding Gramsci’s 'coded' communication with Togliatti, see Rossi and Vacca 2007.

${ }^{29}$ See Q10II, 41, 1311 (June-December 1932), in which Croce’s review is again directly referenced. See also Q10II, §11, 1249 (late May 1932) and Q10II, §14, 1250-3 (late May 1932), in which Gramsci’s problematization of 'prevision' (in quotation marks) is conjugated with considerations on the significance of some of Mario Missiroli’s comments on likely future politico-theoretical developments in Fascist Italy for a comprehension of Croce's recent thought.

${ }^{30}$ Croce was equally dismissive of its application in the natural sciences, which he famously argued only possessed 'general concepts', of a heuristic and instrumental, rather than theoretical, status. See Croce 1907, 236.

${ }^{31}$ On the different stages and emphases of Gramsci’s reading of Machiavelli in the Prison Notebooks, see Thomas 2017.

${ }^{32}$ Gramsci's emphasis upon the importance of the notion of 'effective reality' [realtà effettuale] in Machiavelli's thought is already present in his early notes on Croce's reading of the Florentine secretary; see Q4, §8, 430-1 (May 1930); Q4, §4, 425 (May 1930); Q4, §56, 503-4 (November 1930); Q5, §127, 656-62 (November-December 1930). From 1932 onwards, under the rubric of the 'Modern Prince', it is clearly articulated with the theme of the 'will' and political intervention as decisive elements of its realization; see in particular Q8, §84, 990-1 (March 1932).

${ }^{33}$ On prevision as a 'practico-political intervention in the present', see Frosini 2010, 151.

${ }^{34}$ For an attempt to outline a non-subjectivist theory of political subjectivity or mass intellectuality, see Sotiris 2014. 